\title{
Te veel en heeltemal te min
}

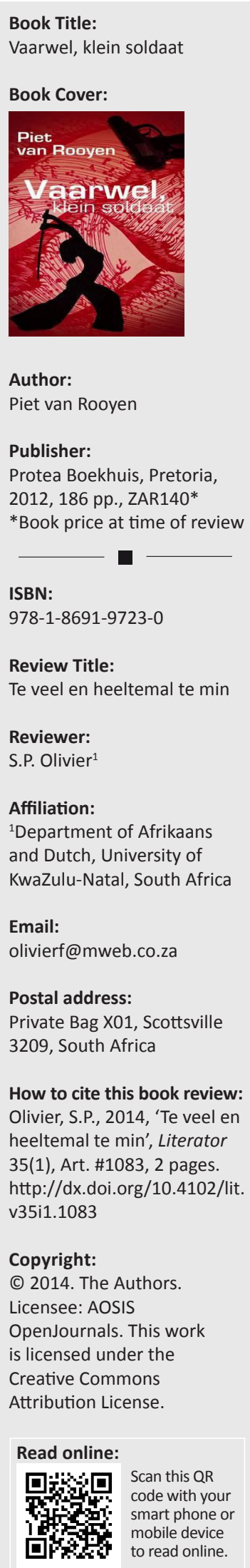

Oor die laaste vyf jaar het die Namibiese skrywer Piet van Rooyen homself stewig gevestig as 'n dikwels meesleurende verteller oor en verkenner van karakters in uitgestrekte woestynlandskappe of die boswêreld van Angola.

Met Vaarwel, klein soldaat, sy 10de roman, verskuif die milieu na die Oos-Vrystaat en Gauteng en betree die skrywer die politieke terrein van regse verset. Die grootste deel van die roman kyk na die werksaamhede van 'n groepie disfunksionele manne, saamgetrek op 'n verlate plaas. Dis die Leër van die Laaste Dae.

Die klein soldaat van die titel is Lulu-pai, die dogter van die bevelvoerder van die verset-/ terreurkommando, Jim Thorpe, en die Chinese vrou (Shirley) wat hy in die destydse Lourenço Marques ontmoet het. Sy het ook 'n jonger suster, Nicola, by Shirley se suster, Maureen.

Dis die aanwesigheid van die vier vroue wat die katalisator word vir die spanning, die moord en die uiteindelike disintegrasie van die Leër.

Thorpe was ' $n$ beroepsoldaat, wat uit die Franse Vreemdeling-legioen oorgespoel het in SuidAfrika, en hom hier te lande met die rassistiese element binne die Afrikanergemeenskap vereenselwig het. So sterk is sy oortuigings dat hy in die jare van politieke oorgang die basis vir die opleiding van die verbitterdes inrig.

'n Nota vooraf verklaar: 'Die verhaal is gebaseer op losstaande gebeure wat werklik plaasgevind het. Tyd is geteleskopeer.'

Die tydgreep waarbinne die roman afspeel, word slordig gehanteer, juis omdat histories kontroleerbare gegewens (die sluipmoordaanvalle op byvoorbeeld Chris Hani en Johan Heyns) uitdruklik verbind word met die aktiwiteite van dié groep, maar op 'n histories verwarrende wyse. Dit is dan die teleskopering waarna die skrywer verwys, maar die vraag bly staan hoekom dit gebeur. Is dit omdat Van Rooyen die geskiedenis bewustelik wil dekonstrueer om so die leser se leeservaring met die werklikheid te vermeng?

Thorpe het twee uiterlike probleme op sy plaas: die uiteenlopende aard van sy soldate en sy dogters se 'ontluikende vroulikheid'. En, uiteraard, die spanning tussen hierdie twee elemente.

Dan is daar ook kaptein Gericke, die plaaslike polisie-offisier, wat vermoed alles is nie pluis op die plaas nie, maar waarskynlik een van die treurigste en mees ongeloofwaardige geregsdienaars is wat ek nog raakgelees het. (Net om in die laaste gedeelte van die verhaal in Gauteng skielik vanaf nêrens soos 'n held op die toneel te verskyn ...)

Maar Thorpe se grootste probleem is ' $n$ innerlike een wat gestalte kry in sy onbeheerste humeur, wat deur die skrywer uitgebeeld word in die man se weersinwekkende optrede teenoor sowel die vroue as sy dogters, veral Lulu-pai.

Die roman, opgebou oor 62 hoofstukke wat oorwegend kort is, kan verdeel word in vyf segmente. Dit begin met bietjie meer as twee hoofstukke waarin die twee meisies op vlug is, dan die langste gedeelte waarin die gebeure op die plaas oorgedra word en vanaf hoofstuk 45 word die aanvanklike vlug voortgesit.

Daar is 'n enkele uiters sentimentele en onoortuigende hoofstuk (61) waarin ons vir Lulu-pai in haar opnuut gevonde heelheid ('Sy is nog sy'!) iewers in die woude van Afrika sien, en 'n laaste hoofstuk waarin 'n opsomming gegee word van wat met almal gebeur het, of sou kon gebeur het.

Die sentrale intrige is die opstand van Lulu-pai teen haar pa. Dit spruit uit die wrede gewelddadige manier waarop haar ma en tante behandel word, die spanning tussen haar en haar pa en, natuurlik, 
die gewaarwording van haar eie seksualiteit. Laasgenoemde gee ook aanleiding tot ' $n$ verhouding met Ruben, een van die kamerade.

Ongelukkig word dit, deur die wyse waarop Van Rooyen vertel, vroeg reeds oorduidelik dat Lulu-pai haar pa sal vermoor. Hiervoor span hy ook gedeeltes uit die meisies se eie 'handboek', The miko (kyk Van Lustbader 1985), in: die volgeling wat die leier, die mentor, moet doodmaak om sodoende eie potensiaal te verwesenlik. Dis uiteindelik 'n verligting vir die leser wanneer Thorpe sterf, onbegrypend, maar tog seker met die wete dat sy klein soldaat nou volledig bevry is.

Die segment waarin die twee meisies se bestaan in die bose stad uitgebeeld word, word eweneens oordrewe en natuurlik heeltemal te vinnig weergegee. Die emosionele belewenis van Lulu-pai gedurende hierdie tydperk en tydens die hofsaak word nooit ter sprake gebring nie. Ook dié wanbalans sou seker onder teleskopering tuisgebring kan word ...

Die roman het tegnies heelwat tekortkominge. Daar is gedurig verskuiwende perspektiewe (wat binne die konteks nie gemotiveerd of aanvaarbaar is nie), stukke werklike swak en sentimentele prosa, fragmente van die storie wat buite verhouding aandag kry, in te veel detail vertel word of sommer net met verskriklike vaart afgehandel word. Van Rooyen se ou kwaal slaan ook weer deur: om deur middel van die vertellinge of gedagtes van 'n karakter feitelike inligting of agtergrond te verskaf.

Ek het terwyl ek lees al hoe meer die gevoel gekry dat die roman iets anders moes wees. Dalk 'n kortverhaal, met die gegewe gesny tot op die been (los byvoorbeeld die twee Chinese vroue heeltemal uit). Of 'n omvattende lywige werk, drie- of vierhonderd bladsye, waarin die familiesage met al sy intriges (soos in Eric van Lustbader se The miko) tot sy volle reg kan kom.

Die feit dat daar saam met Vaarwel, klein soldaat 'n tweede roman van Piet van Rooyen in dieselfde jaar verskyn het (Rodriguez), is miskien 'n aanduiding dat die skrywer te maklik met sy materiaal omgaan en dat sy sukses as skrywer sy uitgewers minder krities maak as wat hulle behoort te wees.

\section{Literatuurverwysings}

Van Lustbader, E., 1985, The miko, Fawcett, Robbinsdale. 